nawcze są stosunkowo łatwo dziś dostępne - dzięki, nagraniom. Wprowadzajmy przy tym chorał do kościoła - co bardzo ważne!! - w postaci językowo nieskażonej, to znaczy $z$ oryginalnym łacińskim tekstem (dopiero na gruntownej znajomości oryginału mogą bazować różne polskie tłumaczenia!).

Mówiąc o krzewieniu kultury chorałowej u nas myślę o jakiejś ałcji integralnej, całościowej, obejmującej zarówno praktyczne nauczanie chorału, jak i całą rozległą, bogatą, historyczno-liturgiczną wiedzę o nim; tu wchodziłyby w grę cykle wykładów i odczytów o formach i gatun' ‘ach chorału, o jego genezie i historii, o jego jakże precyzyjnej systemațzacji według porzadku roku liturgicznego; o jego problemach wykonawczych - o specyficznych $\mathrm{w}$ jego dziedzinie relacjach ,słowodźwięk"; o różnych stylach i sposobach interpretacji wykonawczej chorału dzisiaj. Czy taka akcja, mająca na celu rozmiłowanie wiernych w chorale, w najwyższym, najbardziej uduchowionym - jeśli o muzykę chodzi - pięknie hymnów, mszy, antyfon, responsoriów, jubilacji, sekwencji -- byłaby u nas możliwa?

Pytanie to kieruję pod adresem Szanownego Audytorium. Niech odpowiedzą nań o wiele bardziej, ode mnie kompetentni. Ja osobiście uważam, że innej drogi odnowy nie ma, jak tylko ta chorałowa. 'Ta jedna bowiem będzie rzeczywista, to jest prowadząca do budowy prawdziwego nowego gmachu muzyki kościelnej. Wszystkie inne zaś będą pozorne. Dopiero bowiem na fundamencie chorałowym i w chorałowej atmosferze rozwijać będzie można wątki nowsze, wprowadzać, nadbudowywać inne wartości (na przykład mszę polifoniczną XV i XVI wie-' ku, pieśń religijną renesansu); zawsze wszelako w odniesieniu do tych najwyższych, reprezentowanych przez chorał.

Podkowa Leśna

BOHDAN POCIEJ

Ks. Karol Mrowiec C. M.

\title{
KRYTERIA OCENY PIEŚNI KOŚCIELNYCH .
}

Wartość i wartościowanie stanowią pojęcia, które są ze sobą ściśle sprzężone. Nie jest jednak rzeczą łatwą ustalić, co decyduje o wartości określonej pieśni kościelnej i dlatego w podejmowaniu jej oceny narażeni jesteśmy na wiele pomyłek i trudności należy wypracować właściwe i obiektywne kryteria jej oceny.

Podejmując problem kryteriów oceny pieśni kościelnych, trzeba chyba wyjść od stwierdzenia, że pieśń kościelna nie jest ani pieśnią artystyczną w tym znaczeniu jak np. pieśni Schuberta czy Karłowicza, ani pieś- 
nią ludową sensu stricto, ale jest otwarta na obydwie strony, tzn. ma w sobie coś z pierwszej jak i drugiej, ale z żadną z nich się nie identyfikuje.

Zdawałoby się, że pieśń kościelna (a mam tu na myśli jej wzorcową postać, tzn. taki utwór słowno-muzyczny stroficzny, który jest możliwy do wykonania przez lud podczas służby Bożej) powinna stanowić jałkąś trwałą wartość, ponieważ uczy teologii i jest jej praktycznym wyrazem. Tymczasem zarówno dynamika wspólnot religijnych, jak i rozwój oraz zmiany $w$ poglądach estetycznych prą do zmienności. Ta zmienność właśnie warunkuje i prowokuje do wartościowania. Wartościowanie pieśni kościelnych utrudnia fakt, że nie stanowią one przejawu tzw. wielkiej sztuki, ale raczej są wytworami rzemiosła artystycznego, które należy oceniać w oparciu o inne zasady niż przy analizie dzieł muzyki autonomicznej. Wartościowanie pieśni utrudnia także oddziaływanie na nasze poglądy różnych historycznych kryteriów oceny, jak np. estetyki uczuciowej XVIII i XIX wieku, względnie kryteriów nowych, współczesnych, którym pieśn kościelna nie jest w stanie odrazu sprostać; jak np. kryterium oryginalności formy, niezależnej od jakiegokolwiek tradycyjnego gatunku.

W dotychczasowych próbach oceny wartości. pieśni kościelnych można wyróżnić - idąc za Haraldem Kaufmannem - cztery następujące modele wartościowania:

1. model transcendentny, który da się wyrazić w pytaniu: czy okrèślony utwór jest w ogóle pieśnią kościelną?

2. model zakładanej zgodności między instytucjonalnym charakterem pieśni kościelnej a wymogami estetycznymi, który da się streścić w pytaniu: czy określona pieśń odpowiada każdorazowej sytuacji historycznej?

3. model ruchu odnowy, który da się. sprowadzić do pytania: czy mamy do czynienia $z$ pieśnią starą i dlatego wypróbowaną i dobrą?

4. model socjologiczny, który da się wyrazić w pytaniu: czy określony śpiew ma takie zalety, że trafia do wszystkich warstw społeczności religijnej i tym samym może stać się popularny a nawet swego rodzaju przebojem muzycznym?

Każdy z tych modeli ma swoje słabe strony' i może być sprzeczny z wartościowaniem według innych modeli. Nic dziwnego, że podczas V Międzynarodowego Kongresu Hymnologicznego w Grazu (1969) zaproponowano zastąpienie terminów „wartość” czy „kryterium wartości" słowami ,jakość estetyczna” oraz „funkcja”. Jak z tego podziału widać, wartościowanie estetyczne uznano nadal za jedno z podstawowych zagadnien $w$ ocenie pieśni kościelnych. Jest ono przydatne tak w odniesieniu do dawnych jak i nowych pieśni, gdyż zarówno pieśni XVI w., jak i XIX wieku mogą być dobre lub złe, w zależności od użytych w nich środków artystycznych. Wartościowanie na podstawie funkcji-można by, za F. Müllerem, zdefiniować następująco: ta pieśn 
jest dobra, która umożliwia dzisiejszemu człowiekowi wyrazić swoją wiarę albo atwiera mu drogę do wiary. Tak szeroko rozumiane kryterium funkcji każe jednakże liczyć się $z$ pewnym relatywizmem w wartościowaniu poszczególnych pieśni: wiele bowiem dobrego mogą spowodować niektóre takie pieśni, które od strony teologicznej, jak i artystycznej, mniej znaczą.

Z uwagi na stosunek między estetyczną i użytkową wartością pieśni Marqueritte Jenny wyróżniła cztery kategorie pieśni kościelnych:

1. bez artystycznej i użytkowej wartości;

2. wartościowe artystycznie, a bez wartości użytkowej;

3. wartościowe $z$ uwagi na użytek, a nie artystyczne;

4. wartościowe w obydwu wymiarach.

Rzecz jasna, że wyrokowanie na temat dobrych czy złych pieśni ma swoje uwarunkowania historyczne, jest zmienna, zależy od czasu w jakim one powstały. Hymnologia nie chce w tym względzie rozstrzygać, stawiając sobie jedynie skromne zadanie pomagać w odnalezieniu właściwych rozstrzygnięć, a całą odpowiedzialność w ocenie wartości pieśni pozostawia Kościołowi.

Po tych wstępnych rozważaniach teoretycznych można już przejść do bardziej szczegółowych uwag na temat kryteriów oceny pieśni kościelnych. Dokona się przy tym pewnego sztucznego zabiegu rozdzielenia tekstu od melodii, które w każdej pieśni tworzą jedność, by móc jaśniej ustalić wymogi odnośnie do obu w istocie nierozłącznych elementów każdej pieśni.

\section{A. WYMOGI ODNOŚNIE DO TEKSTU}

1. Tekst musi być przystępny, ale nie może być prymitywny.

2. Tekst nie może posługiwać się staroświeckim językiem, który wymagałby zbyt wielu objaśnień.

3. Tekst nie może być tylko rymowaną teologią, a $z$ drugiej strony nie może być wyłącznie „fascynującą poezją" z fałszywą teologią. Stąd nie może zawierać egzaltowanych myśli, brzmiących przesadnie i nieprawdopodobnie. Współczesna pobożność jest rzeczowa i trzeźwa, a człowiek dzisiejszy odczuwa niechęć do wspólnego śpiewu, który wyraża ucieczkę od spraw świata, wrogie nastawienie do ciała, nadmiernie podkreśla prymat duszy, zawiera legendarne nieprawdopodobienstwa czy tryumfalizm Kościoła.

Wyliczone tu kryteria oceny tekstu wydają się odnosić w pierwszym rzędzie do pieśni nowych. Zachowują jednak swój walor także do pieśni dawnych, o których mniej lub bardziej słusznie utarło się przekonanie, że są obiektywne, budujące, proste, bliskie życiu i prawdziwie ludzkie. Mimo to właśnie w stosunku do dawnych pieśni zauważa się nieraz daleko posuniętą postawę krytyczną bądź u ich użytkow-

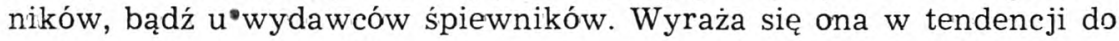


modernizowania tekstów, przed czym należy przestrzec. Często bowiem pierwotny tekst jest bardziej zrozumiały, niż sterta późniejszych poprawek. Przecież i Pismo św. - posługując się porównaniem M. Jenny'ego - nie jest żadną gazetą, ani łatwo zrozumiałą informacją. To co jest trudniejsze $\mathrm{w}$ zrozumieniu, może silniej pobudzić do myślenia i stać się zrozumialszym przez nauczenie się tekstu na pamięć.

\section{B. WYMOGI ODNOŚNIE DO STRONY MUZYCZNEJ}

1. Podstawowym warunkiem, wcale nie nowym a przecież istotnym, jest urzeczywistnienie się w pieśni sensownego związku między słowem a dźwiękiem, albo - mówiąc dokładniej - między mową a muzyką. Schemat stroficzny i melodia stanowią formułę, która kształtuje całą pieśń. O jej jakości decyduje sposób, w jaki obydwa te elementy harmonizują ze sobą. Dobra melodia nie może więc być zwykłą tylko formułą, która zaledwie umożliwia odśpiewanie wszystkich strof. Nie może też być skomponowana po prostu tylko do jednej strofy, lecz musi na równi dawać wyraz muzyczny wszystkim strofom. Dopiero dzięki temu staje się ona formułą wyższego rzędu.

2. Pieśń, jako utwór muzyczny, ma być wartościowa artystycznie, Realizuje się to wówczas, gdy wszystkie elementy dzieła (melodia, rytm, struktura formalna, a w wielogłosowym ujęciu szata harmoniczna i polifoniczna) wykazują znaczne walory estetyczne.

3. Pieśn ma być utrzymana w charakterze i stylu, jaki odpowiada treści utworu, przeznaczeniu do służby bożej i miejscu wykonania.

Styl pieśni kościelnej - jak wiadomo - podlegał zmianom w określonych epokach historycznych. Obecnie lansuje się, zwłaszcza na zachodzie, modne twierdzenie, że pieśń musi być „gemeindengemäss”. Jak rozumieć to określenie? Przecież wspólnota religijna naszych czasów nie przestała być heterogeniczną i trudno przychodzi jej razem znaleźć wspólny język muzyczny dla pieśni. Pod określeniem ,gemeindegemäss" rozumie się przeważnie, iż ma być dopasowana do szlagierowego stylu, a wszystko co sakralne, ma być z niej usunięte. Nie chcąc upraszczać problemu opowiem się za szeroką interpretacją tego terminu, że chodzi o pieśń w nowym, współczesnym stylu, pisaną najnowszymi technikami, jak np. dodekafoniezną, czego udany przykłād -

- zresztą chyba wyjątkowy - spotłać można w szwedzkim śpiewniku kościelnym, stylu - który odpowiadałby mentalności i odczuciu muzycznemu dzisiejszego człowieka. Nie ma chyba wątpliwości, co do słuszności takiego postulatu. Cała jednak trudność leży w tym, jakie cechy musi lub może mieć styl nowoczesnej pieśni, żeby mogła spekniać swą wzniosłą rolę w służbie Bożej? Chodzi chyba o styl, który umie pogodzić zadania stawiane przez Kościół z wymogamí czysto artystycznej natury. O styl, który respektuje próstotę, wynikającą z ograniczonych możliwości wykonawczych śpiewającej wspónoty religijnej 
(przy czym ta prostota grozi popadnięciem w banalność) następnie respektuje pierwszioplanową rolę melodii, a równocześnie jest.otwarty na zdobycze nowej muzyki. Wołanie o nowa pieśń stanowi chyba świadectwo kryzysu, jaki ta forma przeżywa (a może tylko jej stereotypowe przykłady): Z drugiej strony - nowa pieśń za wszelką cenę wydaje się być nonsensem, ponieważ stanowiłaby całkowite zerwanie $z$ tradycją. Lekkomyślne eliminowanie starych pieśni $z$ powodu ich formy, już dlatego jest fałszywym krokiem, ponieważ przez to przecenia się znaczenie formy w stosunku do treści. Muzyka, jak długo jest na usługach liturgii, musi mieć - rzecz zrozumiała - własny język, różny od tego, jakim posługuje się pieśń rozrywkowa. Stąd zacieranie różnicy między stylem - nazwi.jmy go umownie kościelnym - a pozakościelnym nie jest tylko sprawą samych nut, ale także interpretacji, sposobu wykonania, na co także, skoro mowa o pieśni kościelnej, należy zwrócić uwagę.

Nie da się zaprzeczyć, że w dyskusjach na codzień jesteśmy świadkami dwóch przeciwstawnych postaw w ocenie pieśni kościelnych. Jedną reprezentuje starsze, drugą młodsze pokolenie. U starszych zaznacza się uczuciowa ocena melodii pieśni, wynikająca z przywiązania do tradycyjnego repertuaru. U młodszych widać niechęć do wszystkiego, co $\mathrm{w}$ ich odczuciu jest przestarzałe. Obie postawy są na równi jednostronne i trzeba znaleźć złoty środek między szacunkiem dla tradycji a chęcią eksperymentowania. Tradycja bowiem nie staje się automatycznie anachronizmem. I ona zawiera wiele wartościowych, potrzebnych dla zdrowia wspólnoty religijnej odżywczych soków. $Z$ drugiej strony - współczesności nie można uważać za wartość absolutną, lecz zjawisko przemijające, charakterystyczne dla określonego czasu. Te antagonistyczne postawy można określić jako konflikt między tradycją a nową pieśnią, przy tym konflikt ten, utrzymany w rozsądnych granicach, wychodzi obu stronom na dobre. Stwierdzana niejednokrotnie krótkotrwała żywotność nowych pieśni uczy szacunku dla pieśni starych, a wysoka jakość estetyczna i znaczenie funkcyjne dawnych pieśni pobudza do podniesienia poziomu nowych pieśni. W tym sensie można mówić, że stara i nowa pieśn powinny się nawzajem kontrolować.

W badaniach nad wartościowaniem pieśni kościelnych - jak wspomniałem na wstępie - powinno się wypracować możliwie obiektywne kryteria oceny. Ażeby nie zagubić się w szczegółach, unikałem drobiazgowych rozważań nad analizą muzyczną pieśni. Ale taka analiza jest niezbędna, a udoskonalenie jej metod konieczną i pilną potrzebą nauki. Nie mniej trzeba będzie zawsze liczyć się z tym, że przyjęte kryteria wartości nie mogą dać żadnych skutecznych recept na nową twórczość pieśniową. Nowa i wartościowa twórczość zależy niewątpliwie od talentu, doświadczenia i zaangażowania religijnego współczesnych poetów i kompozytorów. 